from child-bearing is practically the same in St. Helens and in Croydon-two towns which differ markedly in general social and sanitary circumstances, and West Ham, a relatively poor and squalid neighbourhood, has a rate lower than that of towns like Brighton, Bournemouth, and Hastings! When it is realised that the mortality from child-bearing varies from 8.54 in Dewsbury to 2.20 in West Ham, it follows that by the adoption of improved measures of care of the prospective mothers before and at childbirth, we may hope materially to reduce what is one of the most pathetic forms of loss of life. The care of prospective mothers is still more necessary at the present time, when there is such a considerable increase in female labour, and such care will, in addition, diminish the number of still-births and of damaged children born.

Not only the maintenance, but the further increase, of our present rate of increase of population must be regarded as one of the most serious and urgent of national problems and responsibilities at the present time. The child is now a national asset of great price, and for the successful rearing of the greatest possible number we must look to improved care of prospective and actual mothers, and improvement of mothercraft and of infant and child welfare.

R. T. Hewlett.

\section{MEDICAL RESEARCH.}

THE first annual report (19r4-19I5) of the 1 Medical Research Committee has been published. It bears date October I8, which is very appropriate, because that is St. Luke's day, the day of the beloved physician. St. Luke's medical knowledge, doubtless, was that which Browning ascribes to Karshish: we have improved on St. Luke, so far as medicine is concerned. This report is a notable bit of work. The Medical Research Committee, as we all know, was born of the Insurance Act, and was endowed, at birth, with a penny in the pound. It was intended to study the diseases of civil and industrial life. It was born in August, rgr3. A twelvemonth later came the war. Pendent opera interrupta-the work on the diseases of dangerous trades, the work on the commoner maladies of our big cities, was more or less declared off. The nation was thrown, all of a sudden, all unprepared, into that most dangerous of all dangerous trades, War.

In this crisis, this day of judgment-for that is the meaning, and the only meaning, of the Greek word crisis-the Medical Research Committee took a very wise course. It added to its first scheme of work a series of proposals for special work, to be undertaken by the committee, in direct connection with the war and for the assistance of the Army Medical Department; and it made up its mind that as the war goes on there will be less and less work to be done for the nation apart from the Navy and the Army.

Not only was the plan of work upset by the war, but the Central Research Institute, the build- ings of the Mount Vernon Hospital at Hampstead, had to be transformed into the Hampstead Military Hospital. And, as the proposals for amalgamation with the Lister Institute, after very careful consideration, have been suspended, we might say that the Medical Research Committee is still without a proper home of its own. But it has found many temporary homes or resting-places for its work, and a welcome for it everywhere.

The researches into subjects connected with the war cover a very wide range. Work has been done at many of the general hospitals of the Territorial Force, and at other military hospitals. Valuable help has been given towards the preparation of the medical history of the war. Wound infections, typhoid and paratyphoid infections, and cerebro-spinal fever have been very carefully studied; so have many problems apart from bacteriology. Special interest attaches to Dr. Leonard Hill's study of asphyxiating gases, and to Dr. John Freeman's expedition to Galicia, whence he brought back cultures of strains of cholera-bacilli, for St. Mary's Hospital to make anti-cholera vaccines for the Serbian Government and for our Mediterranean forces; and to Dr. Leiper's discovery that a fresh-water snail is the intermediate host, between man and man, of the Bilharzia parasite. Other important studies include the work done on "neurological" cases, and the testing of British makes of salvarsan.

In brief, this report is a very fine record of good work done under most unexpected conditions. The moral is, that he or she who works for the forces of the Allies is working also, in the long run, for the nation at home. It is not a weakness, but an added strength, of science, that it can adapt itself to circumstances, and venture into new fields of research at a moment's notice. When the war is over, there will be time enough for the workers under the Medical Research Committee to come back to win other laurels for science in the ways of peace.

\section{FOOD ECONOMY}

A NUMBER of useful pamphlets are being $A$ issued just now on how to economise in war time in the matter of food. One of these, by Prof. W. H. Thompson, of Trinity College, Dublin, we noticed a short time ago. The latest that has come into our hands, entitled "Food Economy in War Time" (Cambridge: At the University Press, price $6 d$.), should be widely read and acted upon. It is written by Profs. T. B. Wood and F. G. Hopkins, both of whom can speak with authority, one from the agricultural, the other from the physiological, point of view. It is written in a clear style, such as the man in the street, or, what is more important, the woman in the kitchen, can understand.

There are many in this country who cannot economise; they already exist on the minimum. Saving must therefore be accomplished by the comparatively well-to-do, and that this can be done without detriment to health is clearly shown.

No. 2409, VOL. 96] 